\title{
TRANSLATING FROM A LINGUA FRANCA IN THE SETTING OF EU TRANSLATION*
}

\author{
Klaudia Bednárová-Gibová \\ Institute of British and American Studies, \\ Faculty of Arts, University of Prešov \\ 1, ul. 17 Novembra, Prešov, Slovak Republic, 08001 \\ klaudia.gibova@gmail.com
}

\begin{abstract}
This conceptual paper explores English as a lingua franca of the supranational translational EU culture by determining translational specificities of EU institutional-legal texts. Set against a specific linguistic and translational background, the problems of equivalence, terminological (in-)congruence, nature of the source text and institutionalization of translation are discussed in order to draw attention to the particularities of the EU's translational practice. Using a synoptic-interpretative approach, different ways of understanding EU discourse and translation are suggested in the paper.
\end{abstract}

Key words: English as a lingua franca, EU texts, EU translation, interpretation, equivalence, terminology, source text, institutionalization

\section{INTRODUCTION}

EU institutional-legal texts (hereafter referred to as 'EU texts') originate under substantial socio-cultural differences among the individual Member States. Therefore, they are marked by distinctive features which are to be considered in their translation into the other official languages ${ }^{1}$. This paper aims to contextualize English as a lingua franca of of the supranational communication, approximate EU texts as a specific discourse and identify its translational specifics which have been so far marginalized in specialized literature focusing on EU translation.

In their nature, EU texts are serious legal documents which are transposed into national legislation in each and every EU Member States. The bulk of EU legislation is known under the French term as so-called acquis communautaire. Every new country wishing to join the EU is obliged to translate the whole acquis into its mother tongue, which becomes a new official language in compliance with the EU's multilingual policy.

\section{* Funding acknowledgement}

This paper is part of the KEGA 007PU-4/2015 Virtual interactive encyclopaedic English-Slovak and Slovak-English dictionary of general linguistics and KEGA 030PU-4/2014 English Stylistics (Discourse Analysis) a Blended-Learning Course research grant projects.

1 To date, there are twenty-four official languages of the EU, these being: Bulgarian, Croatian, Czech, Danish, Dutch, English, Estonian, Finnish, French, German, Greek, Hungarian, Irish, Italian, Latvian, Lithuanian, Maltese, Polish, Portuguese, Romanian, Slovak, Slovenian, Spanish and Swedish. 
Hence, the translation of the acquis into the mother tongues of all the candidate countries prior to the 2004 wave of enlargement of the EU represented the most massive translation project ever materialized in the history of specialized translation. At the time, this was equivalent to well over 80,000 pages. Nowadays, according to the European Commission's estimates the acquis acommunautaire is believed to consist of over 160,000 pages [Bednárová-Gibová 2915: 43].

Even if EU translation has been performed by thousands of practitioners for a good number of decades its serious theoretical treatment started only in the 2000s. Current research avenues in EU translation are based on methodological eclecticism and combine the methods of comparative law, sociology of translation and critical discourse analysis (CDA).

\section{ENGLISH AS A LINGUA FRANCA OF THE EU}

Reference to English as a lingua franca (also known as a bridge language or vehicular language) seems to imply that a language is used systematically to make communication possible between people who do not share a native language. Despite the EU's multilingual policy fostering national languages, English has gained the unofficial role of a lingua franca for a number of pragmatic reasons. English a lingua franca in this communicative environment has been shaped by many linguistic factors which have contributed to its ever-changing shape.

EU texts are produced by a large number of authors from different linguistic and cultural backgrounds, who very often import their own drafting conventions, syntax and stylistic features into the (English) source text. The generic concepts and indefinite semantics of EU English make it a useful vehicular language for conveying compromises and ensuring a mixture of the Member States' national interests. On the other hand, the fuzziness and imprecision of English as a diplomatic tool may also lead to unwanted ambiguities and consequently to misinterpretations [Šarčević 2015: 9].

Traditional studies on global English frequently refer to Kachru's model of worldEnglishes (1985) consisting of three concentric circles: an inner circle consisting of native-speaking countries, an outer circle where English is an official language and an expanding circle where English is learnt as an international language. Based on Kachru's approach, the inner circle is norm-providing since it contains proper standardized varieties of English, the outer is in the process of defining its own varieties and is therefore norm-developing and finally, the expanding circle is norm-dependent [see: Jenkins 2009: 18]. According to Felici [Felici 2015: 129] it proves difficult to classify EU English as a variety because it has no place in Kachru's model which does not take account of specialized use of English. Besides, EU English can be neither norm-providing nor normdependent because the EU institutions strive to avoid terminology linked to national legal systems so as to eliminate country-specific translation problems.

As a result of interactions among drafters (and translators) of different cultures and languages, the translation of EU texts dismisses the traditional concepts of a source text and a target text due to strong elements of deculturalization and the need to ensure uniform legal interpretation of all language versions. As noted by Dollerup [Dollerup 2004: 
197], the source text becomes "a fluid and changeable mass of text, composed of recycled translation". Another specificity of translating from a lingua franca is that EU translators impose neutral tone and general language that is neither source nor target text oriented, but functions as a common denominator [Šarčević 1997: 255]. Lexemes such as subsidiarity, structural funds, public security, mainstreaming or financial envelope may sound strange to the lay citizen, but they have similar equivalents in most EU official languages. In this way, EU drafters aim at developing common terminology. One may agree with Felici [Felici 2015: 138] who argues that English a lingua franca "seems to be the sort of English that best serves the Union's needs in terms of providing acultural neutral expressions, ensuring efficiency and promoting uniformity of all language versions".

\section{EU TEXTS AS A DISCOURSE}

Before pinning down translational specifics of EU translation, the determination of EU texts as a unique discourse should come first. EU texts can be perceived as follows:

1. Hybrid texts [Trosborg 1997; Schäffner and Adab 1997] as a product of translational process within globalization comprising linguistic and translational features which are 'strange or out-of-place' for the receiving culture in lexis, syntax and stylistics. Trosborg primarily views EU texts as hybrid political not legal texts.

2. Reproduced texts [Kjaer 2015] / Linguistic precedents [McAuliffe 2009] which originate in a specific intercultural space at the intersection of many cultures. Reproduced texts are not based on the semantics of a source text, but on a 'linguistic precedent', i.e. the surface level of the wording of prior and parallel texts.

3. Language matrices [Gibová 2010] / Mirror images [Sosoni 2010]) where the template-like nature of EU texts is a consequence of the institutional standardization of their form and linguistic facet, which is manifested by the creation of a homogeneous discourse, that is, by the use of identical means of the language inventory by imitating (the English) source texts.

4. Horizontal texts which have the same meaning [Robertson 2012]. This means that EU texts require a synoptic text approach, i.e. EU texts may be imagined in all their language versions synchronically next to each other and may be semantically compared (However, it should be noted that Robertson's interpretation needs to be examined critically from a point of view of cognitive linguistics. According to major semantic theories, especially to the Sapir-Whorf hypothesis, the construal of meaning is always language specific. Thus, it is not feasible to map out the source language network of concepts on the target language network with utter precision. Moreover, in EU multilingualism there is a supranational pan-European linguistic view of the world which is reflected in the country-specific perspectives of the Member States. Hence, at least the identical legal effect (emphasis added) ought to be achieved in this sort of specialized translation, as called for by Šarčević [Šarčević 1997; 2015]).

In the attempt to define EU translation, function of the texts under discussion appears vital. Šarčević [Šarčević 1997: 215] argues that the function or skopos of EU texts lies in the "fidelity to a single instrument", i.e. all authentic language versions 
of a single legal text represent de facto a single text. This implies then that EU translation should be based on such translation solutions which would fully respect their text function and which would comply with the requirements imposed on these texts in specialized communication. Ramos [Ramos 2014: 314] adduces the following key requirements for EU texts: maximum precision due to achieving semantic unambiguity, formal interlinguistic concordance, harmonization of terminology and intra- and intertextual consistency.

Based on Kjaer's latest interpretation [Kjaer 2015: 93], EU translation involves the reproduction of hybrid texts in twenty-four languages. In this manner, a supranational typological discourse originates in each EU's official language. Hence, it is not the translator's role to adapt EU texts to national legislation texts, but to keep them in the unchanged form. This accounts for why EU translators do not embark on a domesticating journey when they transcreate them into the other languages; why they do not try to get hold of their own language and culture. In my view, EU texts may be viewed as a linguistic imitation of a proto-text (proto-text is a term borrowed from a pre-eminent Slovak translation studies scholar Popovič. The term may be considered synonymous with source text) in order to achieve interlinguistic concordance in all official languages of the EU, which leads to hybrid/reproduced or mirror texts with the identical legal effect.

When contextualizing EU texts in translation theory, EU texts may be approached as retrospective, documentary and semantic translations even though it is necessary to free oneself from structuralist binary oppositions which tend to oversimplify things. Retrospective translation is oriented towards a source text, which is the case of EU translation where the source text holds a strong status, just like in any other kind of legal translation. Documentary translation retains most aspects of the source text (i.e. its morphological, syntactic and lexical structures) so the recipient is well aware of the presence of foreign elements in the target text. One does not succumb to the illusion that they read the original. A certain parallel to documentary translation is represented by Newmark's semantic translation which is marked by a great respect for the source text. Here the translator transfers not only the meaning, but also the form of the original and is heedful of the syntactic structures and stylistic peculiarities of the source text, which is also a reality in EU translation.

A salient translational feature of EU texts is that EU institutions author not only the source text, but also the target text. In this way, 'self-translation' [see: Koskinen 2008] takes place in the EU setting, which is a unique translational situation in comparison to any other sorts of translations. In self-translation, the skopos (in the sense of communicative function) of the source text and its translation remains constant. The constant communicative function of translated language versions creates the illusion that multilingual legislation is drafted simultaneously in all EU's official languages. This means that EU translation may be thought of as a legal co-drafting process which is in translational practice chronological. The next important trait of EU translation is that it is an automatized translation with a heavy use of CAT tools and terminological databases. This, however, does not mean that EU translation can be considered a form of machine translation where the presence of the human factor is markedly absent. 


\section{SPECIFICITIES OF EU TRANSLATION}

In the following, three specificities of EU translation will be scrutinized: 1 . the problem of equivalence, 2 . the problem of terminological (in-)congruity and 3. the problem of the nature of the source text and institutionalization of EU translation.

\subsection{The problem of equivalence}

Equivalence has always been a thorny issue in legal translation. Proponents of equivalence-based theories often define equivalence as the relationship between a source text (ST) and a target text (TT) that allows the TT to be considered as a translation of the ST. (However, Pym has pointed out the problem of the circular relationship between equivalence and translation as equivalence defines translation and vice versa. One of Pym's interpretations [Pym 2010: 7] of equivalence has the following reading: "a relation of 'equal value' between a source language [term] and a target language [term] which can be established on any linguistic level from form to function". This means that equivalence indicates that a SL term and TL term share some kind of sameness, implying an illusion of symmetry between languages). The equivalence-related translational problems are most visible in the translation of legal terms from one legal culture into another where the extent of their legal affinity is wide owing to various legal traditions. In international law, however, where EU texts belong, the situation is a tad simpler in the sense that these texts are drafted and subsequently translated against a relatively unified legal background. According to Sandrini [Sandrini 1999: 15] "the notional equivalence is given and potential problems are only of linguistic or textual nature" (translated by author from the German original. - K.B.).

In light of recent approaches, though, the equivalence with respect to EU translation should be re-considered [Künnecke 2013: 248]. Even if equivalence is commonly defined in translation theory in relation to functional constancy between a source text and target text, in EU translation it has, based on the principle of equal authentic texts (PEAT), an apriori understanding [see: Doczekalska 2005]. A specific feature of EU texts is that they are equivalent not only with the source text, but also with all language versions of a given text. Koskinen [Koskinen 2000: 51] dubs this equivalence existential equivalence. Despite advances in the equivalence theory where it stands as a relative notion influenced by a variety of linguistic and cultural factors, Koller's approach [Koller 1992: 228 - 253] still appears suitable when interpreting EU equivalence. In my view, Koller's denotative and text-normative equivalence play a pivotal role in multilingual EU translation for two reasons. Firstly, correct and legally binding terms require the achievement of denotative equivalence. Secondly, EU translation requires respect for text-forming conventions which are already in use in EU institutions: there is synchronization of language versions based on the synoptic approach in Interinstitutional Style Guide, which contributes to a higher uniformity of EU texts. Koller's connotative and formal-aesthetic equivalence are not applicable to EU translation owing to its legal nature where there is no room for connotations and author's idiolect. From a pragmatic point of view, EU texts have the same legal effect on the receiving culture due to their specific position in every Member State. For this reason, it is not necessary to accommodate their pragmatic equivalence to the target setting. 


\subsection{The problem of terminological (in-)congruence}

Terminology is yet another vexing issue in legal translation not excluding EU translation. Although various terminological databases (e.g. IATE in the European Commission, CURIATerm in the European Court) and terminological memories (e.g. EURAMIS) help translators, the heart of the problem is that EU texts are usually of a very technical nature and their terminology is still under development.

EU translators often consult the translation of specialized terms with national experts who strive hard to endorse a term which is used in a pertinent national legislation regardless of whether a certain term is used in the EU legislation. For illustration, the English term "food supplement" is translated in the Slovak Council Directive 2002/46/ES as "potravinový doplnok", which collides with the Slovak Law on food which also comprises the term at hand, but its definition is different from the European one. For this reason, "food supplement" is translated in the other legalislative acts as "výživový doplnok" [EN: nutrition supplement], which fully corresponds with the definition in the Slovak legislation. The term under discussion serves to demonstrate that EU terminology should be independent of national terminologies since some concepts may reflect different realities (According to Engberg [Engberg 2015: 177-178] the independence of EU terms from national legal systems is only a "legal fiction", because EU terms expressed in national languages are interpreted according to a national legal culture and therefore they cannot be autonomous. Since the supranational terminology is still under development and it lacks legal terms with a deep meaning structure typical of legal semantics, EU terminology and national terminology are in a constant interaction. Biel [Biel 2014: 66] refers to this situation as "conceptual osmosis of terminology", where the terms move between the EU context and national context in both directions.). As it is evident from the above, terminological consultations with pertinent national experts seem vital so as to avoid problems with transposing EU legislation into national legal systems.

\subsection{The problem of the nature of the source text and institutionalization of EU translation}

EU English as a lingua franca is affected by its non-native speakers. According to recent estimates, as few as $13 \%$ of all EU texts are drafted by English native speakers [Ramos 2014: 327]. This leaves a mark on the linguistic facet of English source texts, which are marked by the non-standard use of prepositions (e.g. establish national plans for rare diseases in order to *ensure to patients with rare diseases universal access to high quality care) (Source: http://eur-lex.europa.eu/legal-content/EN/TXT/HTML/?uri= CELEX:52008PC0726R(02)\&from=EN). In standard English,"ensure" should never be followed by "to" and an indirect object [Cf. Gardner 2013: 33]), variations in the use of definite and indefinite articles and non-count nouns (Measures may include specific *actions for the development of financial means) (Source: http://eur-lex.europa.eu/ LexUriServ/LexUriServ.do?uri=CELEX:52011SA0009:EN:NOT) and lexical neologisms (e.g. precisions instead of the established plural lexeme details). All these attributes de- 
crease the natural linguistic idiomaticity of EU English and result in interferences in lexis and syntax, which is symptomatic of the phenomenon known as English as a lingua franca (EFL). In the long run, translating from a hybrid English language which no longer reflects "the mentality and architecture of the English legal culture" may continue to be a problem [Pozzo qtd. in: Šarčević 2015: 84].

Furthermore, the nature of the EU source text is often bound up with a highly complex and unintelligible language of the multilingual Euro-speak which deforms the national languages into an unnatural format [Koskinen 2000: 55]. Thus, national traditions of the Member States' legislation are starting to disappear amidst the ongoing harmonization of European law. For illustration, hypertrophy of coordinative conjunctions in the Slovak language version of the EU text under study may be felt to be stylistically inappropriate, as shown below:

The following actions may be supported under the key activity of policy cooperation [...]: (a) individual mobility, as referred to in Article 5(1)(a), including study visits for experts and officials designated by national, regional and local authorities, for directors of education and training establishments and guidance and experience accreditation services, and for social partners (source: Decision No. 1720/EC).

V rámci klúčovej aktivity spolupráce [...] sa môžu podporit’ tieto akcie: a) individuálna mobilita, ako sa uvádza v článku 5 ods. lpísm. a) vrátane študijných návštev pre odborníkov $\underline{\boldsymbol{a}}$ úradnikov určených národnými, regionálnymi a miestnymi orgánmi, pre riaditelov vzdelávacich zariadeni a zariadeni odbornej pripravy a služieb profesijnej orientácie a akreditácie skúseností, ako aj pre sociálnych partnerov (source: Rozhodnutie EÚ č. 1720/ES).

As can be seen, the Slovak language version imitates the English source text. It could be said that it represents a language matrix which is filled with the Slovak content. Whereas the standard translation is to mould the source text based on its function, EU texts copy the proto-text. Stylistically, I perceive EU texts as hypnotic texts.

There is also a certain paradox in the institutionalization of translation - on the one hand there are efforts to standardize, rationalize and regulate EU translation and on the other hand there is a contradiction in the syntactic reality of EU texts. There are often super-long, breakneck hypotactic sentences which burden the recipient's attention in any language pair, e.g.:

In particular, the Commission should be empowered to adopt delegated acts to specify the particulars that need to be included in the standard agreement between the depositary and the management company or the investment company, the conditions for performing depositary functions, including the type of financial instruments that should be included in the scope of the depositary's custody duties, the conditions subject to which the depositary may exercise its custody duties over financial instruments registered with a central depository and the conditions subject to which the depositary should safekeep the financial instruments issued in a nominative form and registered with an issuer or a registrar, the due diligence duties of depositaries, the segregation obligation, the conditions subject to and circumstances in which financial instruments held in custody should be considered to be lost, and what is to be understood by external events beyond reasonable control, the consequences of which would have been unavoidable despite all reasonable efforts to the contrary (source: Directive 2014/91/EU). 
Komisia by mala byt' predovšetkým splnomocnená prijímat' delegované akty na spresnenie podrobností, ktoré treba začlenit’ do štandardnej zmluvy medzi depozitárom a správcovskou spoločnostou alebo investičnou spoločnostou, podmienok vykonávania funkcii depozitára vrátane typu finančných nástrojov, ktoré by sa mali zahrnút' do rozsahu úloh depozitára v oblasti úschovy (custody), podmienok, na základe ktorých môže depozitár vykonávat' svoje úlohy v oblasti úschovy (custody) finančných nástrojov evidovaných v centrálnom depozitári, a podmienok, na základe ktorých by mal depozitár uschovávat' (safekeeping) finančné nástroje emitované na meno a registrované u emitenta alebo v registri, povinností náležitej starostlivosti depozitárov, povinnosti segregácie, podmienok a okolností, za akých by sa finančné nástroje držané v úschove (custody) mali považovat' za stratené, a čo sa rozumie pod vonkajšimi udalost'ami, ktoré nemožno primerane ovplyvnit' a ktorých následkom by sa napriek všetkej primeranej snahe o opak nedalo vyhnút' (source: Smernica 2014/91/EÚ).

The cited paragraphs above, however, run counter the recommendations in the Joint Practical Guide [Joint Practical Guide 2013: 6] which state that the language of EU texts must be "clear, easy to understand and unambiguous; simple and concise, avoiding unnecessary elements; and precise, leaving no uncertainty in the mind of the reader". This brings us closer to the invidious position of EU translators who are entrapped in the gigantic EU machinery. Among many other things, they are required to abide by the source text and respect its syntactic structure (see Chap. 4 of the Joint Practical Guide). Frame [Frame 2005: 22] speaks in this connection about the so-called "inertia principle" of translation because the restrictions of EU multilingualism and numerous style-guides, which the translators have to abide by, keep their translational decisions limited. This is why the attempts to castigate EU translators mirror one's insufficient knowledge about the specificities of EU translation and their critique often leads to a stalemate.

\section{CONCLUSION}

All in all, translating from a lingua franca may be regarded as both an opportunity and a problem for EU translation. The implications of the paper are that 1) EU texts are a highly specific legal discourse which should be kept apart from traditional legal translation; 2) EU translation should be reconsidered to its specificities as an interlingual imitation of the source text in order to achieve interlinguistic concordance in all EU's official languages, which leads to hybrid/reproduced/ mirror texts with the identical legal effect; 3) particularities of EU translation result from the specific equivalence holding among the individual language versions upholding a symbolic value of all translations, specialized and still developing supranational terminology as well as problematic nature of the source text due to the involvement of non-native speakers and convoluted Eurospeak despite efforts for plain English. In sum, the paper has cast some light on the phenomenon of supranational EU law and its translational practice which reveals very specific realities. 


\section{BIBLIOGRAPHIC LIST}

1. Bednárová-Gibová K. (2015).Towards an Understanding of EU Translation (Habilitation thesis). Prešov, Faculty of Arts of the University of Prešov.

2. Biel L. (2014). Lost in the Euro-Fog. The Textual Fit of Translated Law. Frankfurt am Main, Peter Lang.

3. Doczekalska A. (2005). Production and Application of Multilingual Law. The Principle of Equality of Authentic Texts and the Value of Subsequent Translation. Paper read at Language and the Law 2005: East Meets West.

4. Dollerup C. (2004). The vanishing original. In: Hermes. Journal of Linguistics. No. 32. P. 185 199.

5. Engberg J. (2015). Autonomous EU Concepts: Fact or Fiction? In: S. Šarčević (ed.). Language and Culture in EU Law: Multidisciplinary Perspectives. Ashgate Publishing Ltd. P.169-181.

6. Felici A. (2015). Translating EU Legislation from a Lingua Franca: Advantages and Disadvantages. In: S. Šarčević (ed.). Language and Culture in EU Law: Multidisciplinary Perspectives. Ashgate Publishing Ltd. P. 123-140.

7. Frame I. (2005). Linguistic oddities in the European Union legislation: don't shoot the translator. In: Clarity. Journal of the international association promoting legal language. No 53. P. $21-24$ : http://clarity-international.net/journals/53.pdf.

8. Gardner J. (2013). Brief List of Misused English Terms in EU Publications. Luxembourg, European Court of Auditors,

9. Gibová K. (2010). O preklade anglických právnych textov EÚ. Lingvisticko-translatologická analýza [On Translation of EU English Legal Texts. A Linguistic-Translational Analysis] Prešov, Vydavatel'stvo Prešovskej university.

10. Jenkins J. (2009). World-Englishes. A Resource Book for Students. $2^{\text {nd }}$ ed. London, Routledge.

11. Joint Practical Guide (2013): http://eur-lex.europa.eu/content/pdf/techleg/joint-practical-guide2013-en.pdf.

12. Kjaer A.L. (2015). Theoretical Aspects of Legal Translation in the EU: The Paradoxical Relationship between Language, Translation and the Autonomy of EU Law. In: S. Šarčević (ed.). Language and Culture in EU Law: Multidisciplinary Perspectives. Ashgate Publishing Ltd. P. $169-181$.

13. Koller W. (1992). Einführung in die Übersetzungswissenschaft. Heidelberrg and Wiesbaden, Quelle \& Meyer.

14. Koskinen K. (2000). Institutional Illusions. Translating in the EU Commission. In: The Translator. Vol. 6. No. 1. P. 49-65.

15. Koskinen K. (2008). Translating Institutions. An Ethnographic Study of EU Translation. Manchester, St. Jerome Publishing.

16. Künnecke M. (2013). Translation in the EU: Language and Law in the EU's Judicial Labyrinth. In: Maastricht Journal of European and Comparative Law. Vol. 20. No. 2. P. 243-260: http: //www.maastrichtjournal.eu/pdf_file/its/mj_20_02_0243.pdf.

17. McAuliffe K. (2009). Translation at the Court of Justice of the European Communities. In: Translation Issues in Language and Law. New York, PalgraveMacmillan. P. 99-115.

18. Pym A. (2010). Exploring Translation Studies. London and New York, Routledge.

19. Ramos F.P. (2014). International and supranationallaw in translation: from multilingual lawmaking to adjudication. In: The Translator. Vol. 20. No. 3. P. 313-331: http://dx.doi.org/10.1080/13556509.2014.904080.

20. Robertson C. (2012). The Problem of Meaning in Multilingual EU Legal Texts. In: International Journal of Law, Language \& Discourse.Vol. 2. No 1. P. 1-30. 
21. Sandrini P. (1999) Translation zwischen Kultur und Kommunikation: Der Sonderfall Recht. In: P. Sandrini (ed.). Übersetzen von Rechtstexten. Fachkommunikation im Spannungsfeld zwischen Rechtsordung und Sprache. Tübingen, Gunter Narr. P. $9-43$.

22. Schäffner C. and Adab B. (1997). Translation as intercultural communication - Contact as conflict. In: Translation as Intercultural Communication. Amsterdam/Philadelphia, John Benjamins. P. $325-338$.

23. Sosoni V. (2010) A Hybrid Translation Theory for EU Texts. In: Vertimo Studijos. Vol. 5. P. $76-89$.

24. Šarčević S. (1997) New Approach to Legal Translation. Hague, Kluwer Law International.

25. Šarčević S. (ed.) (2015) Language and Culture in EU Law: Multidisciplinary Perspectives. Ashgate Publishing Ltd.

26. Trosborg A. (1997) Translating hybrid political texts. In: A. Trosborg (ed.). Text Typology and Translation. Amsterdam, John Benjamins. P. 145-158.

УДК: 81'25:651.926

DOІ: $10.22363 / 2313-2299-2017-8-1-148-157$

\title{
ПЕРЕВОД C LINGUA FRANCA В УСЛОВИЯХ ПЕРЕВОДА В ЕВРОСОЮЗЕ*
}

\author{
Клаудиа Беднарова-Гибова \\ Institute of British and American Studies, \\ Faculty of Arts, University of Prešov \\ ul. 17 Novembra, Prešov, 1, Slovak Republic, 08001 \\ klaudia.gibova@gmail.com
}

\begin{abstract}
Эта концептуальная публикация рассматривает английцский язык как lingua franca в наднациональной переводческой традиции Евросоюза путем определения переводческих особенностей институционных юридических текстов ЕС. С учетом специфики языковой и переводческой базы проблемы эквивалентности, терминологической (не-) конгруентности, природы источников текста и институирования перевода обсуждаются с целью привлечения внимания к особенностям переводческих практик, существующих в странах Евросоюза. Применяя синоптико-интерпретационный подход, автор выявляет различные способы понимания дискурса Евросоюза и переводческих практик.
\end{abstract}

Ключевые слова: английский язык как lingua franca, тексты Евросоюза, перевод в Евросоюзе, интерпретация, эквивалентность, терминология, текст-источник, институализация

* Финансовая поддержка: Эта статья является частью проекта KEGA 007PU-4/2015 Virtual interactive encyclopaedic English-Slovak and Slovak-English dictionary of general linguistics и KEGA 030PU-4/2014 English Stylistics (Discourse Analysis) a Blended-Learning Course research grant projects. 